\title{
Cervical pap smear- A prospective study in a tertiary hospital
}

\author{
Pudasaini $\mathrm{S}^{1}$, Prasad KBR ${ }^{1}$, Rauniyar $\mathrm{SK}^{1}$, Pathak R ${ }^{1}$, Pande $\mathrm{K}^{1}$, Koirala $\mathrm{S}^{1}$, \\ Kafle $\mathrm{S}^{1}$
}

${ }^{I}$ Department of Pathology, Nepal Medical College Teaching Hospital, Kathmandu, Nepal

\section{Keywords: \\ Cervical cancer; \\ Pap smear; \\ Screening; \\ Bethesda system; \\ Intraepithelial lesion; \\ Malignancy.}

\begin{abstract}
Background: Cervical cancer is a leading cause of mortality and morbidity among women worldwide and most common gynaecological cancer in developing countries. Papanicolaou smear is a simple and cost effective screening test for cervical cancer. The aim of this study is to evaluate and interpret the cervical pap smear cytology in a tertiary hospital. The interpretation and reporting of the pap smear is based on 2001 Bethesda system.
\end{abstract}

Materials and methods: This is a prospective study conducted in a tertiary hospital, Nepal Medical College over a period of two and a half years (January 2013 to June 2015). All cervical pap smears received in the department of Pathology in the study period were included.

Results: A total of 4160 cervical pap smears were reported in the study period. Majority of the cases were Negative for Intraepithelial lesion or malignancy (87.9\%). Bacterial vaginosis, atrophy and reactive cellular changes associated with inflammation were seen in $5.3 \%, 2.4 \%$ and $1.5 \%$ cases respectively. Epithelial cell abnormalities (0.5\%) include Atypical squamous cells of undetermined significance, Low grade squamous intraepithelial lesion and High grade intraepithelial lesion. 88\% of Low grade squamous intraepithelial lesion was seen in reproductive age group (20-45 years).

Conclusion: Cervical cancer is the most common gynaecological cancer in the developing countries. Pap smear is the simple and cost effective screening tool to detect pre invasive cervical epithelial lesions.

\section{INTRODUCTION}

Cervical cancer is the most common gynaecological cancer leading to death in developing countries like Nepal. ${ }^{1,2}$ The World Health Organization (WHO) Information Centre on HPV (Human Papilloma Virus) and Cervical Cancer states the incidence of cervical cancer in Nepal is $24 .{ }^{2}$ per 100,000 making Nepal a country with one of the highest rates of

\section{Correspondence:}

Dr. Sujata Pudasaini, MBBS, MD

Assistant Professor, Department of Pathology

Nepal Medical College Teaching Hospital, Jorpati, Kathmandu, Nepal

E-mail:sujatapudasaini@gmail.com cervical cancer in the world. Over 2100 cases of cervical cancer are reported in Nepal each year, with a case-fatality rate of over $50 \% .^{3}$

In developing countries, the higher prevalence of cervical cancer is due to ineffective screening programmes. Pap smear is a simple, convenient, cost effective and reliable test for easy screening of cervical lesions. Since its introduction there has been a dramatic reduction in the incidence and mortality of invasive cervical cancer worldwide. ${ }^{4-6}$

The 2001 Bethesda system terminology reflects important 
advances in biological understanding of cervical neoplasia and cervical screening technology and is most widely used system for describing pap smear result. ${ }^{7-9}$

This study is done to evaluate the pattern of cervical pap smear cytology and find out the incidence of epithelial cell abnormalities.

\section{MATERIALS AND METHODS}

This is a prospective study done in a department of Pathology of a tertiary hospital (Nepal Medical College) for a period of two and a half years (January 2013 to June 2015). All cervical pap smears received in the Department of Pathology during the study period were included. Required clinical history of the patients was obtained from the requisition forms and patient's file. Prior to the study, permission was obtained from Institutional Review Committee. Proforma was filled and datea were collectd. A total of 4160 cervical pap smears were reported in the study period. After receiving the slides fixed in 95\% ethyl alcohol, it was stained by Papanicolaou stain by cyto technicians. Slides were then mounted with DPX (Distrene Dibutyl phthalate Xylene) and examined by pathologists. The result of these pap smears was based on 2001 Bethesda System for Reporting Cervical Cytologic Diagnoses (Box 1). The report given by pathologists was based on 2001 Bethesda reporting system.

All the data were manually collected and subsequently analyzed.

\section{RESULTS}

A total of 4160 pap smears were analyzed during the study period (Table 1). The age of the patients ranged from 17 to 78 years. Majority ( $84.7 \%$ ) of the pap smears were form the reproductive age group (20- 45 years). $0.6 \%$ of pap smears were from patients below 20 years and $0.1 \%$ from patient above 75 years. Cervical pap smear findings were tabulated in Table 2.

There were $0.9 \%$ cases of unsatisfactory smear. The most common cause for unsatisfactory smear was obscuring inflammation (55.3\%) where more than $75 \%$ of epithelial cells are obscured. $34.2 \%$ cases showed absence of endocervical/ transformation zone component and 10.5\% showed obscuring blood. $87.9 \%$ cases were Negative for Intraepithelal Lesion or Malignancy.

Epithelial cell abnormalities were seen in $0.5 \%$ cases which include LSIL (0.2\%), HSIL (0.2\%) and ASCUS (0.1\%). LSIL was most commonly seen in reproductive age group (20- 45 years) and HSIL was most commonly seen in peri menopausal age group (46-55 years). Atrophic and reactive cellular changes were seen in $2.4 \%$ and $1.5 \%$ respectively. Organism associated lesion like bacterial vaginosis (5.3\%) and trichomonas vaginalis $(1.5 \%)$ were also seen in our
Table 1: Age wise distribution of total number of patients

\begin{tabular}{ccc}
\hline Age group (years) & $\begin{array}{c}\text { Number of } \\
\text { patients }\end{array}$ & Percentage (\%) \\
\hline$<20$ & 24 & 0.6 \\
$20-45$ & 3524 & 84.7 \\
$46-55$ & 454 & 10.9 \\
\hline $56-65$ & 100 & 2.4 \\
$66-75$ & 52 & 1.3 \\
$>75$ & 6 & 0.1 \\
Total & 4160 & 100 \\
\hline
\end{tabular}

Table 2: Cervical pap smear findings according to 2001 Bethesda System

\begin{tabular}{|lcc}
\hline Interpretation/result & $\begin{array}{c}\text { Number of } \\
\text { cases }\end{array}$ & $\begin{array}{c}\text { Percent- } \\
\text { age (\%) }\end{array}$ \\
\hline $\begin{array}{l}\text { Unsatisfactory for evaluation } \\
\begin{array}{l}\text { Negative for intraepithelial lesion or } \\
\text { malignancy }\end{array}\end{array}$ & 3856 & 0.9 \\
\hline $\begin{array}{l}\text { Low-grade squamous intraepithelial } \\
\text { lesion (LSIL) }\end{array}$ & 9 & 0.2 \\
\hline $\begin{array}{l}\text { High-grade squamous intraepithelial } \\
\text { lesion (HSIL) }\end{array}$ & 9 & 0.2 \\
\hline $\begin{array}{l}\text { Atrophy } \\
\text { Reactive cellular changes associated } \\
\text { with inflammation }\end{array}$ & 68 & 2.4 \\
$\begin{array}{l}\text { Shift in flora suggestive of bacterial } \\
\text { vaginosis }\end{array}$ & 220 & 1.5 \\
\hline $\begin{array}{l}\text { Trichomonas vaginalis } \\
\text { Atypical squamous cells of undeter- } \\
\text { mined significance (ASCUS) }\end{array}$ & 63 & 1.5 \\
\hline \begin{tabular}{l} 
Total \\
\hline
\end{tabular} & 4160 & 0.1 \\
\hline
\end{tabular}

study.

\section{DISCUSSION}

Worldwide cervical carcinoma alone is responsible for about $5 \%$ of all cancer deaths in women. ${ }^{10}$ It has been reported that in developing countries more than 200, 000-300, 000 women die from cervical cancer each year. Initiation of national screening program in the developed countries has resulted in a marked decrease in the cervical cancer related deaths. ${ }^{11}$ Not only in developing countries, tremendous amount of effort is devoted to cervical cancer screening in United States. ${ }^{12}$ The incidence of cervical cancer has decreased more than $50 \%$ in the past thirty years because of widespread screening with cervical cytology. ${ }^{5}$ Considering the efficacy of pap smear cytology in preventing cervical cancer it is advocated that it should be initiated in all women at the age of 21 years. ${ }^{8}$

The age of the patient ranged from 17 to 78 years in our study and the predominant population in the present study was between $20-45$ years ( $84.7 \%$ ). This finding was similar 


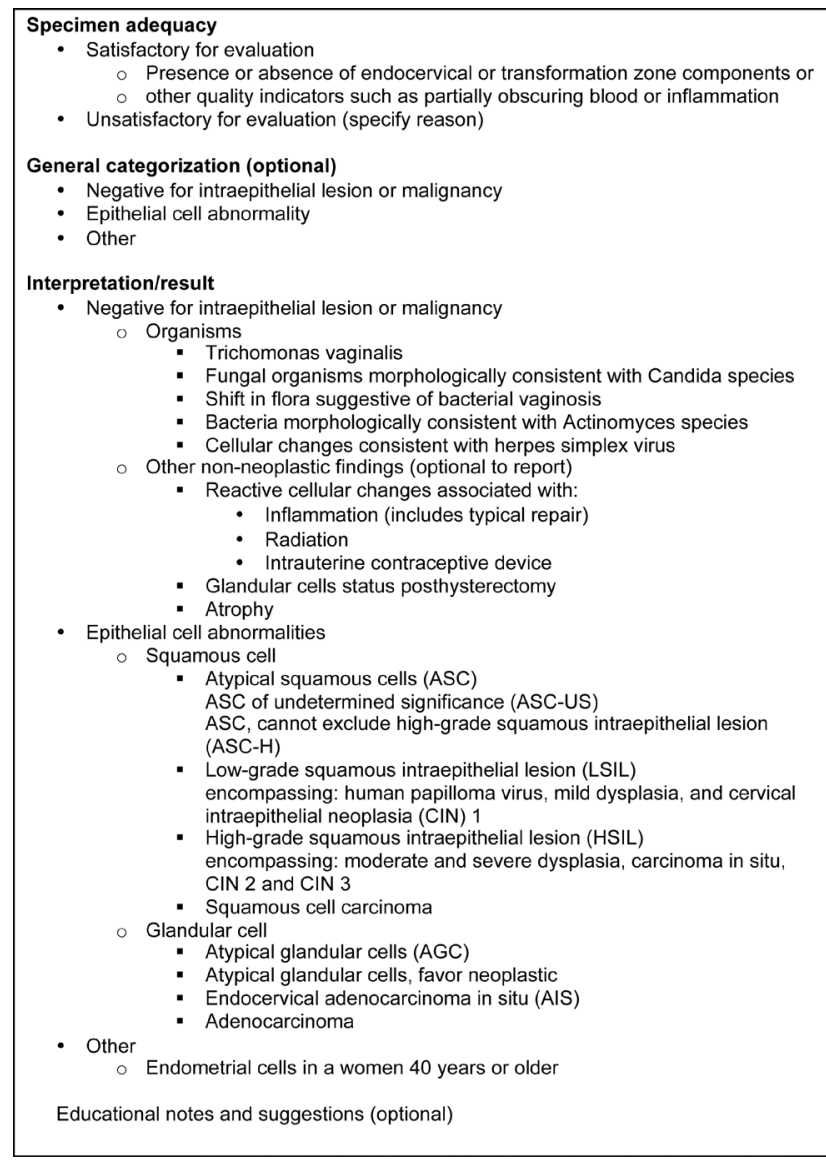

Box 1: 2001 Bethesda System for Reporting Cervical Cytologic Diagnoses

to studies done by Hirachand et al, Ranabhat et al, Bukhar et al and Bamanikar et al. ${ }^{4-6,13}$

$0.6 \%$ of pap smears were from patients below 20 years and similar result $(0.7 \%)$ was seen in study done in Karnataka, India. ${ }^{14}$ However in studies done in mid western part of Nepal and Bangladesh there were no cases below 20 years. ${ }^{5,8}$ Contrast to this and our study the number of cases of pap smear below 20 years was quite high $(11.7 \%)$ in Pakistan. ${ }^{15}$

Getting adequate material in pap smear is difficult at times. There were $0.9 \%$ cases of unsatisfactory smear in our study and the most common cause was obscuring inflammation and absence of endocervical/ transformation zone component. Lots of variation was seen in several studies. Studies done in Kathmandu, Pakistan and India revealed $0.3 \%, 1.8 \%$ and $1.2 \%$ cases of unsatisfactory smear respectively.,6,14 Few other studies showed that the incidence of unsatisfactory smear to be quite high $(11.9 \%, 9.5 \%, 5.7 \%$ and $4.8 \%) .{ }^{9,11,13,16}$

Negative for Intraepithelal Lesion or Malignancy was seen in $87.9 \%$ cases which correlates well with study done by Bamanikar et al in a tertiary hospital $(88.93 \%) .{ }^{13}$ In studies done by Vaghela et al and Saha et al, Negative for Intraepithelal Lesion or Malignancy were seen in $47 \%$ and $50.6 \%$ respectively. ${ }^{16,17}$
Epithelial cell abnormalities represented $0.5 \%$ cases in our study which includes LSIL, HSIL and ASCUS. Studies had shown that the prevalence of epithelial abnormalities were different in different places $(1.7 \%, 1.8 \%, 10.3 \%, 5.6 \%$, $1.8 \%, 2.0 \%, 1.2 \%$ and $13.6 \%)^{5,14,17-22}$ In a study done in the same hospital in 2010, epithelial cell abnormalities were seen in $1.1 \%$ cases. ${ }^{23}$ Since then there is decrease in epithelial cell abnormalities which could be due to inclusion of pap smear as a routine screening procedure for cervical cancer. LSIL $(0.2 \%)$ seen in our study was similar to other studies $(0.15 \%, 0.3 \%$ and $0.2 \%))^{4,5,8}$ Most of the cases of LSIL had mild dysplasia and morphological features consistent with HPV cytopathy. HSIL was seen in $0.2 \%$ cases in our study. Studies done in Nepal and India showed findings $(0.29 \%$, $0.7 \%$ and $0.3 \%$ ) similar to our study. ${ }^{4,5,8}$ Cases of ASCUS $(0.1 \%)$ was also quite comparable to other studies $(0.51 \%$, $0.23 \%$ and $0.2 \%) .{ }^{4,5,8}$ However in one study done in Gujarat India, the incidence of ASCUS (40.74\%) was quite high. ${ }^{19}$

LSIL and HSIL were most commonly seen in reproductive (20- 45 years) age group and perimenopausal (46-55 years) age group respectively which correlates well with study done by Hirachand et al. ${ }^{4}$ Other studies revealed epithelial cell abnormalities in age group 40 years and above..$^{8,19}$

Atrophic changes were seen in $2.4 \%$ cases which correlates well with studies done in Bangladesh (3.0\%), India (2.2\%) and Pakistan (3.1\%). ${ }^{8,9,11}$ Bacterial vaginosis (5.3\%) was common among the organism associated lesion in our study. Other studies revealed $5,4 \%, 1.6 \%, 7.1 \%$ and $8.8 \%$ cases of bacterial vaginosis respectively. ${ }^{14,16,17,22}$ Trichomonas vaginalis was seen in $1.5 \%$ cases in contrast to other studies where there were $3.2 \%, 0.7 \%$ and $0.6 \%$ cases. ${ }^{17,19,20}$ Reactive cellular changes $(1.5 \%)$ seen in our study was associated with inflammation. Two studies done in India revealed $3.2 \%$ and $26.8 \%$ cases of reactive cellular changes. ${ }^{17,19}$ This shows that interpretation of reactive cellular changes is very subjective and hence the results are variable.

Pap smear examination should begin as soon as the female are sexually active irrespective of their age and should be practiced as a routine gynaecological screening program. Implementation of pap screening program in all parts of Nepal is necessary for early detection of cervical premalignant lesions.

\section{CONCLUSION}

Pap smear is a very effective screening tool for early detection of premalignant and malignant lesions of the cervix. The 2001 Bethesda system used for cervical cytology is a standard method and gives descriptive diagnosis that helps the gynaecologist in individual patient management. Awareness regarding the utility and importance of pap smear should be created among all the women worldwide. 


\section{REFERENCES}

1. Tamrakar SR, Chawla CD. A clinical audit of pap smear test for screening of cervical cancer. Nepal Journal of Obstetrics and Gynaecology 2012;7:21-24.

2. Pradhan B, Pradhan SB, Mital VP. Correlation of pap smear findings with clinical findings and cervical biopsy. Kathmandu Univ Med J 2007;5:461-7.

3. Johnson DC, Bhatta MP, Smith JS, Kempf M-C, Broker TR, Vermund $\mathrm{SH}$, et al. (2014) Assessment of High-Risk Human Papillomavirus Infections Using Clinician- and Self-Collected Cervical Sampling Methods in Rural Women from Far Western Nepal. PLoS ONE 9(6): e101255. Crossref

4. Hirachand S, Bajracharya J, Pradhanang S, Lama S. Detection of abnormal cervical cytology in papanicolaou smears in a tertiary care center. J Nepal Med Assoc 2013;52:462-5. Crossref

5. Ranabhat SK, Shrestha R, Tiwari M. Analysis of abnormal epithelial lesions in cervical pap smears in Mid-Western Nepal. Journal of Pathology of Nepal 2011;1:30-3. Crossref

6. Bukhari MH, Saba K, Qamar S, Majeed MM, Niazi S, Naeem S. Clinicopathological importance of papanicolaou smears for the diagnosis of premalignant and malignant lesions of the cervix. $J$ Cytol 2012;29:20-5. Crossref

7. Solomon D, Davey D, Kurman R et al. The 2001 Bethesda system: Terminology for reporting results of cervical cytology. JAMA 2002;287:2114-9. Crossref

8. Yeasmin S, Begum T, Begum LN, Ahmed ASMM, Osman B. Pap smear study and its utility in cervical cancer screening in a tertiary care hospital in Chittagong, Bangladesh. Chattagram Maa-O- Shishu Hospital Medical College Journal 2014;13:17-9. Crossref

9. Patel MM, Pandya AN, Modi J. Cervical pap smear study and its utility in cancer screening to specify the strategy for cervical cancer control. Natl J Community Med 2011;2:49-51.

10. Mansoor I. Profile of cervical smears cytology in western region of Saudi Arabia. The internet journal of Gynaecology and Obstetrics 2001;1:1-5

11. Khan MS, Raja FY, Ishfaq G et al. Pap smear screening for pre cancerous conditions of the cervical cancer. Pak J Med Res 2005;44:111-3

12. Sirovich B, Welch G. The frequency of pap smear screening in the United States. J Gen Intern Med 2004;19:243-50. Crossref
13. Bamanikar SA, Baravkar DS, Chandanwale SS, Dapkekar P. Study of cervical pap smears in a tertiary hospital. Indian medical Gazette $2014 ; 250-4$.

14. Renuka N, Sultana A. Cytopathological study of cervical smear: a hospital based retrospective study. Medical journal of Islamic World Academy of Sciences 2014;22:42-9. Crossref

15. Haider G, Parveen Z, Anjum F, Munir A. Pap smear, an important screening tool to detect precancerous stage of carcinoma of cervix. $\mathrm{J}$ Ayub Med Coll Abbottabad 2013;25:26-7. Crossref

16. Vaghela BK, Vaghela VK, Santwani PM. Analysis of abnormal cervical cytology in papanicolaou smears at tertiary care center- a retrospective study. IJBAR 2014;5:47-9.

17. Saha K, Sengupta M, Mistry CJ. Cytological findings of conventional cervical papanicolaou smear in a tertiary care hospital. Global Research Analysis 20113;2:149-51.

18. Nair RV, Shwetha BR, Manju A, Solanke PV. Papanicolaou (Pap) test screening in a tertiary care teaching hospital in South India. IJMSCI 2015;2:1260-5.

19. Tailor HJ. Patel RD, Patel PR, Bhagta VM. Study of cervical pap smears in atertiary care hospital of South Gujarat, India. Int J Res Med Sci 2016;4:286-8 Crossref

20. Selhi PK, Singh A, Kaur H, Sood N. Trends in cervical cytology of conventional pap smears according to revised Bethseda system: a study of 638 cases. IJRRMS 2014;4:16-20

21. Rizvi JH. Rasul S, Ghazali B, Jamal A. Screening fro cervical cancer by pap smear. JPMA 1988;38:229-31

22. Verma I, Jain V, Kaur T. Application of Bethesda system for cervical cytology in unhelathy cervix. J Clin Diagn Res 2014;8:26-30.

23. Marahatta Khanal R. Value of conventional cervical cytology as a screening test for cervical cancer. Nepal Med Coll J 2014;16:63-7. Crossref 